\title{
Concerts and dances in a library? An undergraduate library as campus cultural space
}

$\mathbf{T}$ he title of this article is taken from the not really surprising reaction we sometimes get from students and visitors. Aren't libraries supposed to be quiet places for studying and student work? As we seek to diversify academic library cultural offerings, similar to our public librarian colleagues, having concerts and dances in a library is a way to open the library to the community in an intriguingly different way, and to enhance curriculum by offering a new venue for students to perform in and for their audiences, as well. This article will examine some of the types of collaboration that have taken place as a result, the benefits to our students as well as to ourselves, and some how-to's.

\section{Background}

Powell Music in the Rotunda is a free concert series offered by the UCLA College Library, the campus undergraduate library, featuring UCLA students, faculty, and staff with occasional professionals who are willing to perform for free. It offers a venue for students outside the music building. The concerts are held in the second floor Moorish-style rotunda under a Romanesque dome with a very resonant acoustic, which of course plays a role in determining what type of music can be performed. There is a very small budget. Staffing consists of one librarian, with some limited assistance from other library staff and student workers to move furniture and set-up chairs, and a couple of staff volunteers to assist during the concerts themselves.
The original concert series ran for about 24 years, from 1966 to 1990. The building, one of the original campus buildings constructed between 1927 and 1929, was earthquake renovated and upgraded in the mid-1990s. After the renovation in 1998, College Library staff member Karen Baxter decided to resurrect the series. When she left UCLA in 2000, I took over its management. In 2002, a historical dances series was added. The current series is now almost 15 years old, and it has changed and grown since it began.

The rotunda's resonant acoustics determine what types of music can be played, for instance modern piano is not possible. Types of music that have been performed include early music (choral, instrumental, and keyboard), classical guitar, strings, choral, world music (e.g., Near Eastern, Balkan, Northern Indian), woodwinds, a cappella, jazz, and pop. At the beginning, the series consisted mostly of afternoon concerts. As the concerts grew in quality and complexity, they became almost exclusively held on Friday and Saturday evenings when the library is closed, except for the end of the term during finals when the library is open $24 / 7$. The audiences have changed from consisting of primarily undergraduate students to a mixture of campus and community. Daytime concerts did have

Catherine M. Brown is inquiry librarian for lead, exhibits, and programs at UCLA College Library, e-mail: cbrown@ library.ucla.edu

() 2014 Catherine M. Brown 
the advantage of introducing this music to the students who happened to be studying on the second floor where the concerts are held.

\section{Collaborations}

These are the three departments, now under the umbrella of the UCLA Herb Alpert School of Music, whose students, faculty, and staff have performed in Powell over the years. Originally Karen Baxter collaborated with department outreach liaisons who conveniently obtained groups and individuals for her. After these people left, bookings have mostly occurred through people contacting me directly.

The most successful collaborations involve faculty or very motivated students acting on their own, sometimes performing their cap-

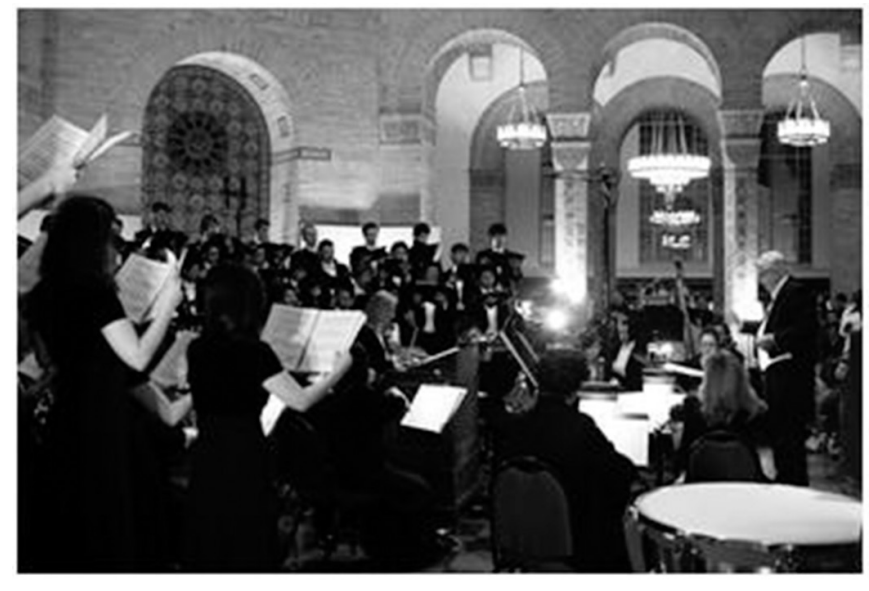

stone recitals. Donald Neuen conducts the UCLA Chorale and Chamber Singers. We have also Photo by Henry Lim

had a number of professional chamber musicians looking for suitable venues in Los Angeles and are willing to perform for free. Our own music students had to audition to get into their program, and because they are very good, additional auditions are not required.

There have been a variety of collaborations with faculty, graduate students, undergraduates, and student organizations such as a cappella groups. Each one arises from a desire to perform in a unique space outside the music building theaters in a convenient but unique and intimate venue. This interest is also fed by the reputation the Powell music series has built up over the years.

How did our collaborations arise? One model was via an interested graduate student, with others following and eventually including their faculty. Another resulted from an introduction by one faculty to another interested colleague, which in turn may lead to additional collaborations. In both instances, this resulted in direct ties between the concerts and the music school's curriculum.

By 2006, some groups and individuals that I had worked with over the years had left, and the well seemed to be running dry. Winding down the series seemed to be a possibility. Up until then, due to our acoustics which lent itself to early music, I had mainly worked with the Musicology department, but not with the Music department itself, apart from a few individual students.

Then late that year, a choral conducting graduate student attended a concert and decided to have his final doctoral recital here. After collaborating with several subsequent choral conducting graduate students for a series of choral concerts, this chapter culminated with the choral conducting professor Donald Neuen and his graduate students conducting the full UCLA Chorale and Chamber Singers, with more than 100 members and a chamber orchestra, in two performances of Bach cantatas in January 2011.

In fall 2000, Music department faculty member Tom Beghin began a series of early keyboard recitals featuring students from his classes. In 2002, he departed UCLA, but turned over the idea of performing in Powell to his colleague, Musicology Professor Elisabeth Le Guin. UCLA does not have an early music program per say, but in an effort to resurrect campus early musicmaking from the past, Le Guin began teaching a series of early music workshop classes, which were open to nonmusic majors.

Eventually through her persistence and hard 
work, this culminated in the establishment of an official Early Music Ensemble, which was now open to students in the Music Department. Their first concert was held fall 2009, and featured vocal and instrumental groups, including the UCLA Brass Ensemble with two different groups of trumpets and trombones facing each other and performing Giovanni Gabrieli antiphonal Renaissance music under the rotunda dome, the kind of space the music was originally composed for.

Since then, other talented graduate students have taught the class, and directed the concerts. Powell Library became the home venue for this ensemble, and the class has been held every quarter since 2012. It has become one of the only opportunities for our music students to learn how to perform vocal or instrumental music from the Medieval through Baroque periods. Without the Powell Library series,

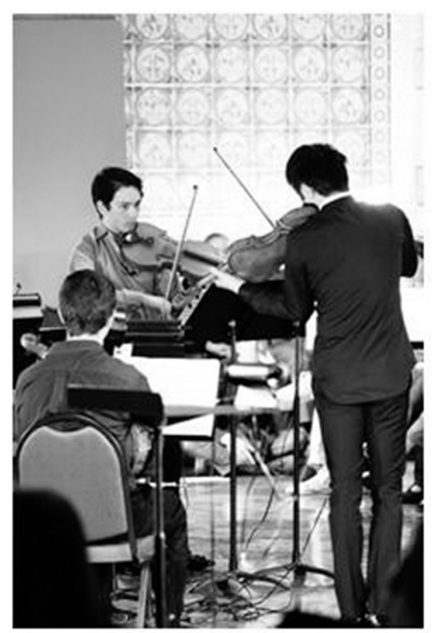

Daniel Stephens and Richard O'Neill. Photo by Henry Lim it's doubtful this ensemble would exist. ${ }^{1}$

At a concert in 2008, another Musicology professor introduced me to Violin Professor Movses Pogossian. This began the annual Vivaldi concerts in which freshman violin students, in their second quarter, take turns performing The Four Seasons in addition to other works. This steadily grew to include cello and viola Strings faculty also performing with their freshmen students. The concert is held the same weekend as the Strings' auditions for new students, and has been used as a recruiting tool with some success. This has contributed in a small way to the Music Department's strategic plan to increase the quality of their students and therefore attract and retain top international caliber faculty.

As the Music department strategic plan notes, "UCLA is now competing for students, and often winning, against Julliard, Eastman, Indiana, Michigan, Rice, Oberlin, USC and others because of the high level of faculty instruction." 2

It has become an important Strings tradition, with students who performed previous years in the audience cheering on their younger colleagues.

One of the important music pedagogies that take place in the Vivaldi concert and others, are students performing alongside their professors. The two photos on this page illustrate this

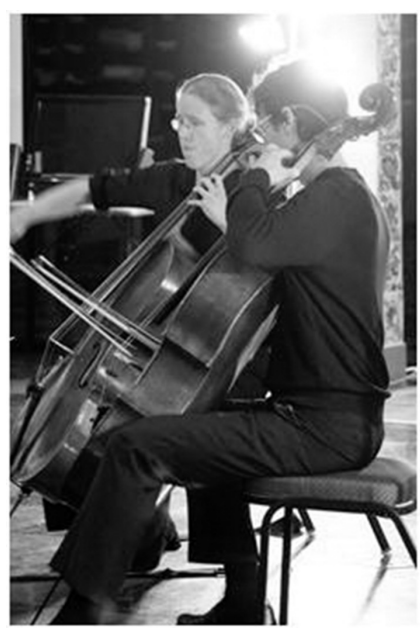

Chloe Knudsen-Robbins and Antonio Lysy. Photo by Henry Lim concept. In the first, Viola Professor Richard O'Neill performs a Bach Brandenburg concerto with his freshman student. The other is from a series of concerts featuring the Bach cello suites, with the graduate student on the left, and Professor Antonio Lysy on the right.

\section{Campus student groups}

A cappella has a strong following here at UCLA, and a cappella groups have performed in Powell since the mid-2000s. Lately we have had to cut back on the number of concerts and have discontinued a cappella, but the Powell rotunda has always been very popular with these groups and attract a number of sorority and fraternity members in the audience for a fun evening.

Another long tradition has been the Historical Dances in the Rotunda series, which now 
features three dances per year with themes like "Waltz Night," "Italian Renaissance Ball," and "Jane Austen Ball." These are coordinated by a pair of professional dance instructors who also teach at meetings of the ballroom dance clubs on campus. Emma Lewis Thomas, emeritus dance professor, provides expert instruction at the annual Renaissance Ball, and lately they've begun to feature live music, with our own music students performing occasionally. These events are a lot of fun and quite popular with our students, as well as members of the community.

\section{Pointers}

While another article (or even a book) could be written on running such a music and dance series, here are a few pointers gleaned over the years:

- be open and accommodating;

- make it easy for the performers;

- publicity, publicity, publicity;

- set up early rather than too late;

- get assistance when possible; and

- never stop learning.

\section{Publicity}

In rough order of effectiveness, the following is a list of types of publicity done for our concerts and dances:

- e-mail messages to departments,

- chamber music community newsletters and website calendars,

- library website updates, ${ }^{3}$

- listings on other department/campus calendars,

- posters and flyers in libraries and some departments,

- concert e-mail list (sign-up book at concerts), and

- social media.

The e-mail messages to departments are sent once a quarter, as typically departments prefer not to have updates more often than that. It's important to include all departments, and, if possible, professional schools on campus. For example, audience numbers noticeably increased after science and engineering departments were added to our e-mail list.

\section{Benefits}

How does a well-suited, high-profile venue benefit faculty's work, their department's curriculum, and thereby their students? In her opening remarks at the inaugural concert of the newly reconstituted UCLA Early Music ensemble, Elisabeth Le Guin remarked:

The reconstitution I'm referring to here has to do with curriculum, with the support and that legitimacy that this provides. Until this Fall, an early music ensemble had not been offered for ensemble credit to music majors since $1989 .{ }^{4}$

How do concerts and other similar events benefit libraries, which, in some cases, may be experiencing declining gate counts? In the literature, two authors have stated:

academic libraries...are...striving to engage the community of users and potential users in new ways 5

and

The concerts gave us a unique visibility that conventional university outreach did not... ${ }^{6}$

During fall 2012, we conducted a brief feedback assessment from our student audience. One student wrote, "these concerts are an absolute treasure. I hope to perform here myself someday." Another stated, "the Powell Concert series is one of the gems of the UCLA. The library is such a unique space and really allows music to be presented in new fresh ways, making it accessible to different audiences outside the traditional 'concert hall' setting."

So, what about potentially disturbing music in a library filled with students studying? When I asked then University Librarian Gary E. Strong how you balance use by students for quiet study versus use as an events venue, he said "very delicately."

Part of this delicate management has to do with posting signage warning students how long they can expect the sounds from rehearsals or 
performances (welcome or not) to continue, and where they can go to study if they are disturbed. If this is not enough, in the past, staff at the reference desk encouraged students to leave a note in the library's suggestion box. This seems to take care of most complaints, and there seem to be more students listening to a concert or a rehearsal than appear to be hostile to it.

Concerts have been held at the Library of Congress since 1925. In this era of redefining the role of the academic library, one of the oldest types of cultural programming is still attracting audiences and members of the campus and wider community. Perhaps your library can also establish "... one of the campus's outstanding treasures."

\section{Notes}

1. Video of the UCLA New Music Ensemble performing David Lang's "I Lie" is available at https://www.youtube.com/watch? $\mathrm{v}=\mathrm{zR}$ _bs9aslWg and a performance of Hildegard von Bingen's "Ave, generosa" is at https:// www. youtube.com/watch?v=RJzeD4HHnxs.

2. Michael Dean, et al., "A Strategic Plan for the UCLA Department of Music: University of California, Los Angeles," Fall 2012, retrieved from www. senate.ucla.edu/.../UGC/.../5AProgressReport_Music_Spring2013.pdf.

3. Information on the Music at the Rotunda series is on the UCLA College Library website at www.library.ucla.edu/libraries/college/ powell-music-dances.

4. Elisabeth Le Guin, "Welcome," Jubilate: Motets and Canzone from Baroque Italy and América concert, Los Angeles, California, November 21, 2009.

5. Deborah A. Robertson, Cultural Programming for Libraries: Linking Libraries, Communities \& Culture (Chicago: ALA, 2005).

6. Bonnie Biggs, "Quiet Study Area: No Applause Between Movements," CERL News (1991): 17.

7. Joseph Nagy, e-mail message to author, June 13, 2012. n

("Addressing college student loan . . " cont. from page 376)

that can engage and unite an entire college or university community, both on and off campus. Simply put, the face of the student debt challenge is the face of a particular student who we know, a student who is struggling because of this problem.

For the benefit of that student and many thousands of others, we must reduce student debt.

\section{Notes}

1. Christina Chang Wei and Laura Horn, Federal Student Loan Debt Burden Of Noncompleters (Washington: National Center for Education Statistics, 2013).

2. Richard Fry, "Young Adults, Student Debt, and Economic Well-Being," Pew Research Social \& Demographic Trends, www.pewsocialtrends.org/2014/05/14 /young-adults-student-debt-and-economic -well-being/ (accessed May 30, 2014).

3. American Student Assistance, "Student Loan Debt Statistics" (2014), accessed May 30, 2014, www.asa.org/policy/resources /stats/.
4. Institute for College Access \& Success, "Quick Facts About Student Debt" (2014), accessed May 30, 2014, http://projectonstudentdebt.org/files/pub/Debt_Facts_and_Sources. pdf.

5. Ibid.

6. Richard Fry, "Young Adults, Student Debt, and Economic Well-Being," Pew Research Social \& Demographic Trends, pewsocialtrends.org/2014/05/14 /young-adults-student-debt-and-economic -well-being/ (accessed May 30, 2014).

7. American Student Assistance, "Student Loan Debt Statistics" (2014), accessed May 30, 2014, www.asa.org/policy/resources/stats/.

8. Jonnelle Marte, "Many Blind To College Loan Needs," Boston Globe, www. bostonglobe.com/busness/2014/05/24/many-blind -college-loan-needs/cQ7BoYPUPk1DaB5cWHX6kL /story.html (accessed May 30, 2014).

9. ACRL, "ACRL President Trevor A. Dawes' Presidential Initiative" (2014), accessed May 30, 2014, www.ala.org/acrl/acrl-president -trevor-dawes-2013-14-presidential -initiative. $\boldsymbol{n}$ 